This item was submitted to Loughborough's Research Repository by the author.

Items in Figshare are protected by copyright, with all rights reserved, unless otherwise indicated.

\title{
Technical and user evaluation of a novel worm-based, on-site sanitation system in rural India
}

PLEASE CITE THE PUBLISHED VERSION

http://dx.doi.org/10.3362/1756-3488.2016.013

\section{PUBLISHER}

(C) Practical Action Publishing

\section{VERSION}

AM (Accepted Manuscript)

\section{PUBLISHER STATEMENT}

This work is made available according to the conditions of the Creative Commons Attribution-NonCommercialNoDerivatives 4.0 International (CC BY-NC-ND 4.0) licence. Full details of this licence are available at: https://creativecommons.org/licenses/by-nc-nd/4.0/

\section{LICENCE}

CC BY-NC-ND 4.0

\section{REPOSITORY RECORD}

Furlong, Claire, W.T. Gibson, A. Oak, G. Thakar, M. Kodgire, and R. Patankar. 2019. "Technical and User Evaluation of a Novel Worm-based, On-site Sanitation System in Rural India". figshare. https://hdl.handle.net/2134/22017. 
C. Furlong (claire.furlong@ymail.com) is currently a Research Associate in Urban Sanitation at the Water, Engineering and Development Centre, Loughborough University, Loughborough, UK and was the Sanitation Innovation Manager at Valley Ventures Limited, Tarporley, UK;

W.T. Gibson (waltergibson@bearvalleyventures.com) the Director of Bear Valley Ventures Limited, Tarporley, UK;

A. Oak (aoak@primoveindia.com)is the Director of PriMove Pvt Ltd, Pune, India;

G. Thakar (gthakar@primoveindia.com)is an Environment Specialist at PriMove Pvt Ltd, Pune, India;

M. Kodgire (mkodgire@primoveindia.com)is a Project Manager at PriMove Pvt Ltd, Pune, India;

R. Patankar (rpatankar@primoveindia.com) is a Design Engineer at PriMove Pvt Ltd, Pune, India

This work was funded by USAID DIV (grant number AID-OAA-F-13-00049) awarded to Bear Valley Ventures Ltd. The advice and support of Dr Adam Biran at the London School of Hygiene and Tropical Medicine for the user research is gratefully acknowledged. Additionally, we would like to acknowledge the support of the Bill \& Melinda Gates Foundation through a grant awarded to the London School of Hygiene and Tropical Medicine, which funded the initial research and development of this technology. 
The technical performance and user acceptance of a novel on-site sanitation system based on vermifiltration was tested for over 12 months in rural India. Ten households (mean household size $=5.6$ people) who had previously practised open defecation trialled a pour flush toilet linked to a vermifilter, together known as a 'Tiger Toilet'. Technical parameters which were monitored over this period included: usage, temperature, accumulation of faecal matter and vermicompost, presence of worms, and influent and effluent quality. User satisfaction was evaluated relative to a baseline survey and through focus group discussions. The vermifilters processed human waste products effectively in a real life scenario. After 12 months there was little accumulation of faecal solids (0-10 per cent surface coverage) and effluent quality was good (chemical oxygen demand reduction $=57$ per cent, faecal coliforms reduction $=99$ per cent). Vermicompost accumulation was low and suggested that emptying would only be necessary every five years. User satisfaction levels were high, with 100 per cent of respondents being either very satisfied (60 per cent) or satisfied (40 per cent) with the 'Tiger Toilet'. The main reasons given were the use of worms and the lack of smells.

Keywords: Eisenia andrei, composting, faecal sludge, vermicompost, wastewater

THERE ARE 2.4 BILLION USERS of on-site sanitation globally (Muspratt et al., 2014) with 1.8 billion people relying on basic pit latrines (Graham and Polizzotto, 2013). Traditional on-site sanitation systems such as pit latrines or septic tanks simply contain the waste and periodically require emptying or re-siting. The major problem with traditional systems is the accumulation of faecal sludge, which is often discharged into the environment without any form of treatment (Massoud et al., 
2009). The lack of safe collection and treatment of faecal sludge is the weakest link in the on-site sanitation service chain which leads to an enormous impact on the environment, particularly water resources, and human health. Additionally there has been a lack of innovation in this sector, highlighted by grants to stimulate creativity. This means that many people have little choice in terms of the technology available to them.

Interest in vermifiltration (a filter containing worms) as a form of on-site sanitation has arisen because of the significant challenges associated with traditional on-site sanitation systems which include: cost, space requirements, difficulty in emptying which may lead to the reintroduction of pathogens into the local environment, and lack of treatment of faecal matter (Thye et al., 2011; Furlong et al., 2014b). An improved on-site sanitation solution needs to be identified which addresses the sanitation service chain from containment through to treatment and reuse or disposal. Household-scale vermifilters may represent a solution to the challenge of achieving sustainable on-site sanitation, since they reduce the amount of solids within the system through the bioconversion of waste into vermicompost (worm waste), when the food chain is extended with worms (Xing et al., 2014). This has the potential to reduce the frequency of emptying and the footprint of the system. Additionally worms reduce pathogens to the level where the vermicompost can be safely applied to land (Eastman et al., 2001); furthermore the vermicompost produced is a dry compost rather than a wet sludge, which makes it easier to empty and transport.

Vermifilters show promise as they are at least as efficient, if not more so, as more traditional treatment processes such as the activated sludge process ( $\mathrm{Li}$ et al., 2011) and septic tanks (Furlong et al., 2014b). They are known to stabilize organic 
matter (Arora et al., 2014; Xing et al., 2014; Wang et al., 2011; Zhao et al., 2010, 2014.), reduce biochemical oxygen demand (BOD) and chemical oxygen demand (COD) (Arora et al., 2014; Furlong et al., 2014b; Kadam et al., 2009; Kumar et al., 2014; Wang et al., 2011), nitrogen (Wang et al., 2011), and phosphorus (Furlong et al., 2014b; Wang et al., 2011), and increase dissolved oxygen (Arora et al., 2014; Wang et al., 2011) in the effluent. Nitrification has been recorded (Furlong et al., 2014b; Wang et al., 2011) due to the aerobic conditions, and is a concern because of its role in groundwater contamination and eutrophication. Many studies have shown a reduction in bacterial pathogens and indicator organisms in vermifilter effluent (Arora et al., 20014; Furlong et al., 2014b; Kadam et al., 2009; Wang et al., 2011). Interestingly traditional vermicomposting of sewage sludge has been shown to greatly reduce bacterial pathogens and, more interestingly, helminth ova (Eastman et al., 2001), although other studies have disputed this (Bowman et al., 2006; Hill et al., 2013).

Our initial research showed that Eisenia fetida was able to process fresh human faeces under wet conditions and that simple vermifilters showed potential for use as an on-site sanitation solution (Furlong et al., 2014a, b). The present study takes this technology out of the laboratory and into the field. To our knowledge, this research is currently the only study that explores the use of a vermifilter as an on-site household sanitation system. The aim of this study was to test this technology in situ with families in rural India and to evaluative both the technical performance and user acceptability.

\section{Methodology}

The field trials in India were set in a rural village approximately $60 \mathrm{~km}$ from Pune, in Maharashtra State. The village was chosen as it had a piped water supply (the toilets 
require water), a relationship was previously established with the villagers during previous work (environmental development planning), and because of the ease of accessibility for monitoring.

Ten households (56 people) were recruited for this trial. A small sample size was used as this was a proof of concept study which required extensive monitoring and was high risk, so a larger trial would have been inappropriate. The following recruitment criteria were used for households:

- $\quad$ The household did not have a sanitation system.

- $\quad$ The household size (including all children) was less than 10.

- $\quad$ The household owned the house and land around it.

- $\quad$ The household was willing and able to contribute 2,000 rupees to the cost of construction and aid with the labour and materials.

- $\quad$ The site had a soil percolation rate $\leq 25$ s/mm (BS 6297; British Standards Institution, 1983).

A household size of 10 and below was required as it was estimated that the system can cope with the waste from 10 people. A contribution was required to give the households a sense of ownership of the toilets. As the effluent was infiltrated into the soil below the system a reasonable soil percolation rate was required.

Informed consent was gained from the head of the household and they were able to withdraw from the trial at any time. If they withdrew or at the end of the trial, they became the owners of the toilet and if requested it could be turned into a traditional twin pit latrine pour flush toilet. After recruitment a survey was undertaken to gain further information on the households. 


\section{Vermifilter construction}

The 10 field prototype vermifilters were constructed in brick. The bedding layer consisted of $10 \mathrm{~cm}$ of locally produced compost and the drainage layer was made of graded aggregate $(60 \mathrm{~cm})$, the top layer being sand. The vermifilter had a diameter of $1.2 \mathrm{~m}\left(\right.$ area $\left.=1.1 \mathrm{~m}^{2}\right)$ and was $1.25 \mathrm{~m}$ deep. The design incorporated an inspection chamber where the influent sample was collected and a vertical perforated pipe to allow an effluent sample to be collected. The vermifilter was set in the ground and the effluent infiltrated into the surrounding soil. Each vermifilter was seeded with $2 \mathrm{~kg} / \mathrm{m}^{2}$ of locally sourced Eisenia andrei (composting worms, a close relative of E. fetida). The users were instructed on how to use the system; i.e. how to flush the toilet, not to use bleach or to put anything other than water down the toilet. The vermifilters were offset from the brick superstructure and connected to a pour flush squat pan (Figure 1) via the inspection chamber: together these parts are the 'Tiger Toilet'.

Figure 1 Newly constructed Tiger Toilet, showing the tank and collection pipe in the background

\section{Monitoring of vermifilters}

All 10 vermifilters were monitored weekly using structured observations and interviews with the users for the first month, then five representative vermifilters (chosen to be varied in terms of user family size and soil percolation rates) were monitored monthly until month 4 then at months 6, 9, and 12. The structured observations were recorded on a standardized form and included an inspection of the superstructure and tank. Smells, the presence of flies and cleaning products in the 
superstructure were recorded. The tank was opened and the volume of faecal material was estimated, by the surface area it covered (percentage surface coverage). The presence, location, and depth of vermicompost were recorded, as was the presence of worms. The temperature in the bedding layer was measured as in Furlong et al. (2014b).

\section{Influent and effluent samples}

Influent and effluent samples were taken after a month and then when the vermifilters were being monitored. Influent samples were collected over a period of 24 hours in the inspection chamber by blocking the outlet pipe (Figure 1), this was homogenized and then sampled. The effluent sample was collected via a perforated (holes of 1-cm diameter) pipe (1.10 m x $10 \mathrm{~cm}$ diameter), which was open at both ends. A collection vessel was placed at the bottom of the pipe to block infiltration into the ground for one week prior to sampling. The effluent sample was allowed to settle before the supernatant was decanted for analysis. This method was used because vermicompost is washed from the top of the vermifilters into the sample pipe, therefore the decanted sample would be more representative of the effluent which was being infiltrated into the soil below the system. The influent and effluent samples were analysed by an external accredited laboratory for thermotolerant coliforms (IS 15185; Bureau of Indian Standards, 2002), COD (IS 3025: Part 58; Bureau of Indian Standards, 2006) and total solids (IS 3025: Part 15; Bureau of Indian Standards, 1984).

\section{Monitoring of usage}


To ascertain usage, the doors of the monitored superstructures were fitted with a door counter and households were also asked to complete a usage sheet on a daily basis. Data were collected when the vermifilters were being monitored.

\section{Baseline and end-line survey}

Baseline data was collected using an administered survey. The topics covered included household demographic and economic status, current sanitation practices, and satisfaction with these. After the system had been used by the households for 12 months an end-line survey was conducted, with the same respondents who completed the baseline survey. This survey was undertaken to gauge any change in opinion. The topics covered included household details (as the population is highly mobile), user understanding of technology, and satisfaction with the new system, which included feedback on improving the system.

\section{Focus group discussions (FGDs)}

FGDs were undertaken with three sets of users. The groups were split by age and then gender for adults (10 children aged 8-16, 10 women aged 35-55, and 10 men aged 30-60). Participants of the FGDs had not completed the surveys. The main aim of the FGDs was to gauge each group’s understanding of the system, to gain feedback on the process and user experience. A guide was used to stimulate the discussion, which included the following questions:

- What was the building/installation process like?

- How does the system work?

- $\quad$ Did you have any initial concerns or worries about the system or using worms? 
- What do you like or dislike about the system?

- $\quad$ Did anything surprise you about the system?

- Would you change anything?

- $\quad$ Is there anything else you would like to discuss or add?

The FGDs were recorded and transcribed: they took between 30 and 45 minutes.

\section{Results and discussion \\ User profiles}

Of the users 30 were male and 26 were female and they ranged in age from 2 to 80 years old, with a mean age of 35 years. At least two people in each household farmed their own land, and the household monthly income ranged from US\$57 to \$317 (mean \$115). Over half of the households invested further in tiling and painting of the superstructure, highlighting their willingness to invest in sanitation.

\section{Usage}

The door counters were not robust. One failed in month four and this household did not keep a consistent record of usage. Additionally another failed in month 12. From the door counter data the number of visits recorded ranged between one and seven visits per person per day. The mean number of visits across all vermifilters over the 12 months was between three and four visits per person per day. The number of selfrecorded visits ranged from one to three, with an average of two to three visits per person per day. The door counter records when the door was opened and closed, therefore it was known that this would probably over-estimate usage. Additionally it was thought that self-recorded usage would be under-recorded. Therefore it was thought that the number of visits per person was approximately three a day. These data together with that from the temperature sensor show that the vermifilters were 
consistently used throughout the one year trial. It should be noted that all of the systems monitored experienced periods of high usage including one that had an extra 35-40 users for one day (shock loading). It was noted that this did not impact the system and the excess waste was processed quickly. Previous work has shown that vermifilters are able to cope with periods when no faeces are added (Furlong et al., 2014 b). These scenarios illustrate the adaptive nature of vermifilters.

\section{Temperature in the vermifilters}

The temperature sensors had failed in all but two of the vermifilters after six months, probably due to the humidity in the systems. The data that were available were analysed. The mean temperature across the systems over the six months was $30^{\circ} \mathrm{C}$, but the temperature ranged from 20 to $41^{\circ} \mathrm{C}$ over this period (Table 1 ).

Table 1 Temperature in the bedding layer over the first six months

\begin{tabular}{ccc}
\hline Month & Min temperature $\left({ }^{\circ} \mathbf{C}\right)$ & Max temperature $\left({ }^{\circ} \mathbf{C}\right)$ \\
\hline 1 & 20 & 38 \\
2 & 26 & 39 \\
3 & 29 & 39 \\
4 & 30 & 41 \\
6 & 25 & 39 \\
\hline
\end{tabular}

This was much higher than the maximum temperature in the first prototype tested in the United Kingdom of $24^{\circ} \mathrm{C}$ or in the laboratory-based experiments (Furlong et al., 2014a). The temperature range for E. fetida (and therefore E. andrei) is $4-40^{\circ} \mathrm{C}$ with optimum temperature of $15-20^{\circ} \mathrm{C}$ (Edwards and Bohlen, 1996. It should be noted that the worms were acclimatized to environmental temperatures as they were sourced from a local worm farm. The vermifilters were found to be cooler during the day, when they were in use, and hotter at night when unused. In Figure 2 it can be seen that cool periods correlate to when the systems were being used (i.e. 
flushed with water), which was further evidence of usage. This was due to the phenomenon of cooling via the flushing of the system, which was also observed in the laboratory scale vermifilters and the first prototype (Furlong et al., 2014b).This phenomenon could be used to cool the system in extremely hot climates.

Figure 2 Hourly temperature in the bedding layer

\section{Structured observations}

During the first four weeks two incidents were recorded, one to do with flushing with water and one concerning the use of cleaning products. Throughout the subsequent months there were no problems with cleaning products, flies, or odour in the superstructure or tank.

After 12 months there was between 0 and 10 per cent surface coverage of faecal matter meaning that the worms in the system were consuming the daily load of faecal material almost immediately on entering the system. The acclimatization period for the worms was approximately 60 days (HH3-HH5, Figure 3): at the end of this period the worms had consumed the faecal matter that had accumulated and were almost processing the material that was added daily. In laboratory scale systems this acclimatization period took six weeks (Furlong et al., 2014b). It should be noted that acclimatization may have occurred after six weeks in the field prototypes, but at this stage they were only being monitored monthly. Household 1 (HH1, Figure 3) was the household that was not using enough flushing water. This may have slowed the processing of faecal matter due to the formation of ammonia in the pan, which would then have entered the vermifilter. E. fetida hence E. andrei are known to be sensitive to high levels of ammonia (Edwards and Bohlen,1996). Household 2 (HH2, Figure 3) 
received 35-40 guests during week two hence it took longer for the accumulated material to be digested by the worms.

Figure 3 The percentage of the surface of the vermifilters covered in faeces

Vermicompost started to accumulate within two weeks of use, which was quicker than in the laboratory scale and the UK prototype (Furlong et al., 2014a). This was thought to be because of the higher temperatures in the field compared with these earlier systems, which speeded up the metabolism of the worms. Due to the processing of the worms, the vermicompost was pushed to the edges of the system (Figure 4). After 12 months the depth of the vermicompost varied between $1 \mathrm{~cm}$ and 9 $\mathrm{cm}($ mean $=4 \mathrm{~cm})$. As the area of the vermifilters is $1.1 \mathrm{~m}^{2}$, this means between 11 and $99 \mathrm{~kg}$ (mean = $44 \mathrm{~kg}$ ) of vermicompost were generated in one year (assuming a density of $1 \mathrm{~kg} / \mathrm{m}^{3}$ ). The average number of users was six; therefore they would have generated approximately $432 \mathrm{~kg}$ of faeces per year which would mean $1 \mathrm{~kg}$ of faeces is converted into $100 \mathrm{~g}$ of vermicompost. This bioconversion is within the range seen in laboratory-scale experiments, where $1 \mathrm{~kg}$ of faeces was converted into between 100 and $190 \mathrm{~g}$ of vermicompost (Furlong et al., 2014 a). From this it can be estimated that the vermifilter would only need to be emptied after five years or longer.

The worms themselves were found to be elusive and have only been seen in one of the vermifilters, but this is quite normal as the worms feed from below the waste. The accumulation of fresh vermicompost is an indication that the worms are present and processing the waste. 
Figure 4 Inside the tank after 12 months; the photo also shows the sample collection pipe

\section{Effluent quality}

In Table 2, it can be seen that the mean thermotolerant coliform removal was $2-\log _{10}$ (99 per cent), which was consistent with data from the laboratory trials (Furlong et al., 2014a). The COD removal was lower than anticipated (Table 2), which was due to the influent being of better quality than expected in terms of COD (and thermotolerant coliforms). When this was explored it was found that approximately 15 litres of water was being used daily by each person, whereas in the UK prototype 5 litres was being used per person per day (Furlong et al., 2014a). Although the removal rates are low compared with the results from the laboratory-scale systems and the UK prototype, in absolute terms the effluent quality was higher. Total solids reduction was consistently high across the systems and the year. It should be noted that these are very conservative estimates of the effluent quality as the sampling method would have also captured non-treated effluent. Additionally as the effluent infiltrated into the soil, further treatment will have occurred, through the action of soil microorganisms. As the system is aerobic it has been noted in our previous work that nitrification occurs (Furlong et al., 2014b), but it is believed that the interface between the vermifilter and the soil would be anoxic, meaning denitrification would occur.

Table 2 Influent and effluent values for the field trials

\begin{tabular}{llll}
\hline Parameters & \multicolumn{3}{c}{ Mean } \\
\cline { 2 - 4 } & $\begin{array}{l}\text { Influent } \\
(\mathbf{n}=\mathbf{1 0})\end{array}$ & $\begin{array}{l}\text { Effluent } \\
(\mathbf{n}=\mathbf{1 0})\end{array}$ & $\begin{array}{l}\text { Reduction }^{1} \\
(\mathbf{\%}, \mathbf{n}=\mathbf{1 0})\end{array}$ \\
\hline TTC $(\mathrm{cfu} / 100 \mathrm{ml})$ & $\begin{array}{l}471,400 \\
(\mathrm{sd}=284,350)\end{array}$ & $\begin{array}{l}2,010 \\
(\mathrm{sd}=978)\end{array}$ \\
COD $(\mathrm{mg} / \mathrm{l})$ & 275 & 104 & 99 \\
& & & 57
\end{tabular}




\begin{tabular}{|c|c|c|c|}
\hline & $(\mathrm{sd}=84)$ & $(\mathrm{sd}=28)$ & \\
\hline Total solids (mg/l) & $\begin{array}{l}202 \\
(\mathrm{sd}=83)\end{array}$ & $\begin{array}{l}61 \\
(s d=19)\end{array}$ & 69 \\
\hline
\end{tabular}

[NOTE]TTC, thermotolerant coliforms; sd, standard deviation

$[\mathrm{NOTE}]^{1}$ geometric mean

\section{Survey results}

It should be noted that throughout the trial the users were actively interested in the monitoring of the system (i.e. looking into the vermifilters when they were being inspected). This seemed to give them confidence that the system was working, especially when so little fresh waste was present (Figure 4).

In the baseline survey respondents were asked about the main problems with open defecation. They cited the lack of privacy as their major concern (Figure 5). The 'others' category in Figure 4 included fear of dogs (30 per cent, $n=10$ ), fear of wild boar (20 per cent, $n=10$ ), and being criticized by neighbours (10 per cent, $n=10$ ). When asked the same question after they had been using the vermifilter for one year, no problems or worries were listed, except in one case where a householder expressed concern about the lid of the system (in the current design the lid is split into two to allow for ease of monitoring).

Figure 5 Main concerns with open defecation

During the baseline survey 70 per cent $(n=10)$ of those asked were very dissatisfied with their current sanitation practice; 30 per cent $(n=10)$ were dissatisfied. The main reasons given for these ratings were as follows: it was a bad practice, inconvenience during rainy season, lack of privacy and overcrowding, embarrassment specifically for women, and criticism from neighbours. After 12 
months of use people were either very satisfied (60 per cent, $n=10$ ) or satisfied (40 per cent, $n=10$ ) with the Tiger Toilet. The most popular reasons given were: use of worms and technology (40 per cent, $n=10$ ), convenience (40 per cent, $n=10$ ), lack of smell (20 per cent, $\mathrm{n}=10$ ) and lack of mosquitoes (30 per cent, $\mathrm{n}=10$ ). When asked what they disliked most about the system, most of the feedback was about the design of the lid (40 per cent, $n=10$ ) and the height of the pit in the rainy season (20 per cent, $n=10$ ). These are features which can be easily amended in the next prototype.

The respondents unanimously found the Tiger Toilet to be better than open defecation for reasons of convenience and safety. All participants said that they would recommend the vermifilter to a neighbour because it was convenient and problem free. All participants were happy to continue to use the system.

\section{User FGDs}

All of those who participated in the FGDs could describe how the vermifilter worked. As one child explained '...excreta accumulates in the pit. Worms are placed in the pit and use this excreta as food and convert it into compost'. There was consensus across all groups that it was a good toilet and that it was working well and all groups would recommend it to a neighbour. As one women stated '... we are using this system for more than one year. There are no problems of waste accumulation and odour. So this system is good'. While a male respondent stated:

...there are three tiger toilets close together. Ours is big family of about 10-11 people and we are all using the system daily. Our toilet is located on main road. Still our neighbours as well as pedestrians do not complain 
C. FURLONG et al.

of odour (from the toilet). This is why I think the system is good and has no problems.

The children and men's groups actively discussed their initial worries. One child stated:

...we have never seen before that worms convert excreta into manure. So initially we were not sure about the performance of the system. Later on after a month when we could actually see compost in some of the systems all the uncertainties were resolved.

The men were more worried that the system would not work as it was a novel technology,

I was very happy to have my own toilet. However I was not sure about the performance of worms and their survival and [I] was afraid that if the system failed it would cause epidemics and odour problems. However after eight days when the pit was opened by your team for observation, [there was] no odour or mosquito problem. Thus most of my concerns were resolved.

Additionally another participant stated

I was worried that if the worms did not work, my family and neighbours will have problems with odour and bad smells and our neighbours may not allow us to use the system ... However after one month I could observe that excreta being decomposed and problems of smell and 
mosquito breeding were not observed, I was very satisfied with the system.

The users liked the fact that the systems were monitored so they could actually see what was happening in the vermifilter.

All groups were asked about improvements to the systems; they spoke about increasing the space in the superstructure, reducing the footprint by removing the inspection chamber, improving the lid, and the use of other lower cost materials for the superstructure. There was a lot of positive feedback from this group about the systems and most participants thought it was a good technology. As one participant stated, 'we have been using system for about a year. Hardly $5 \mathrm{~cm}$ of the pit is filled. No excreta is accumulating. Conversion of excreta into compost is taking place immediately. This system is very good'. When asked what they liked about the system it was generally the lack of smell and flies, although one respondent liked the idea of using the compost. It should be noted that vermicomposting in India is common and vermicompost is a valuable product.

Feedback from all FGDs and the end-line survey was very positive. This may have been influenced by the study design as the majority of the cost of the systems was paid for by the project. Additionally the participants may have wanted to please the researchers because of the prospect of ongoing projects in their village. The study tried to address this bias by using participant contribution and triangulation of feedback from multiple users, different user groups, and using different methods (i.e. survey and FGDs).

\section{Conclusion}


Although this was a small, proof of concept trial, the vermifilter prototypes performed beyond expectations under household conditions in rural India. The technology proved to be robust and able to handle periodic shock loading beyond the design criteria of 10 users. The conversion of faeces to vermicompost took approximately 24 hours, meaning there was very little faecal material present in the systems. Significant mass reduction occurred due to the bioconversion to vermicompost, leading to an estimated emptying frequency of less than once every five years. Additionally the effluent quality in terms of COD, thermotolerant coliforms, and total solids was improved significantly by this system.

User satisfaction with the Tiger Toilet was high, contrasting markedly with the previous levels of dissatisfaction with open defecation. The key drivers for satisfaction were the use of worms and the lack of smells. It should be noted that this was the trial of a first field prototype, therefore improvements can still be made (some of which were highlighted by the users). The next challenge is to make a scalable and economically viable prototype for this market. This study proves that the Tiger Toilet (which is a simple vermifilter) has huge potential to meet the needs of households for on-site sanitation.

\section{References}

Arora, S., Rajpal, A., Kumar, T., Bhargava, R., and Kazmi, A. A. (2014) ‘A comparative study for pathogen removal using different filter media during vermifiltration', Water, Science and Technology 70(6): 996-1003. DOI: 10.2166/wst.2014.318 
C. FURLONG et al.

Bowman, D.D., Liotta, J.L., McIntosh, M., and Lucio-Forster, A. (2006) ‘Ascaris suum egg inactivation and destruction by the vermicomposting worm, Eisenia foetida', Proceedings of the Water Environment Federation 2: 11-18.

British Standards Institution (1983) BS6297; British standard code of practice for design and installation of small scale sewage treatment works and cesspools.

Bureau of Indian Standards (1984) IS 3025: Methods of sampling and test (physical and chemical) for water and wastewater : Part 15 Total residue (total solidsdissolved and suspended), New Delhi: Bureau of Indian Standards.

Bureau of Indian Standards (2002) IS 15185: Water quality: Detection and enumeration of Escherichia coli and coliform bacteria: Membrane filtration method, New Delhi: Bureau of Indian Standards.

Bureau of Indian Standards (2006) IS 3025: Methods of sampling and test (physical and chemical) for water and wastewater: Part 58 Chemical oxygen demand (COD), New Delhi: Bureau of Indian Standards.

Eastman, B.R., Kane, P.N., Edwards, C.A., Trytek, L., Gunadi, B., Stermer, A.L., and Mobley, J.R. (2001) 'The effectiveness of vermiculture in human pathogen reduction for USEPA biosolids stabilization’, Compost Science \& Utilization 9(1): 38-49.

Edwards, C.A. and Bohlen, P.J. (1996) Biology and Ecology of Earthworms, London: Chapman and Hall.

Furlong, C., Gibson, W.T., Templeton, M.R., Taillade, M., Kassam, F., Crabb, G., Goodsell, R., McQuilkin, J., Oak, A., Thakar, G., Kodgire, M., and Patankar, R. (2014a) 'The “tiger toilet”: from concept to reality’, IWA Specialist Conference on Municipal Water Management and Sanitation in Developing 
C. FURLONG et al.

Countries,2-4 ${ }^{\text {th }}$ December 2014 Bangkok, Thailand. Published by the International Water Association.

Furlong, C., Templeton, M.R., and Gibson, W.T. (2014b) 'Processing of human faeces by wet vermifiltration for improved on-site sanitation', Journal of Water, Sanitation and Hygiene for Development. DOI:

10.2166/washdev.2014.107

Graham, J.P. and Polizzotto, M.L. (2013) 'Pit latrines and their impacts on groundwater quality: a systematic review’, Environmental Health Perspectives 121: 521-30. DOI:10.1289/ehp.1206028

Hill, G.B., Lalander, C.H., and Baldwin, S.A. (2013) 'The effectiveness and safety of vermi- versus conventional composting of human feces with Ascaris suum ova as model helminthic parasites', Journal of Sustainable Development 6(4): 1$10<$ http://dx.doi.org/10.5539/jsd.v6n4p1>.

Kadam, A.M., Nemade, P.D., Oza, G.H., and Shankar, H.S. (2009) 'Treatment of municipal wastewater using laterite-based constructed soil filter’, Ecological Engineering 35(7), 1051-61. doi:10.1016/j.ecoleng.2009.03.008

Kumar, T., Rajpal, A., Bhargava, R., and Prasad, H. (2014) 'Performance and evaluation of vermifilter at different hydraulic loading using river bed material', Ecological Engineering 62: 77-82.

doi:10.1016/j.ecoleng.2013.10.028

Li, Y.S., Xiao, Y.Q., Qiu, J.P., Dai, Y.Q., and Robin, P. (2011) 'Continuous village sewage treatment by vermifiltration and activated sludge process', Water Science and Technology 60(11): 3001-10. doi: 10.2166/wst.2009.715 
C. FURLONG et al.

Massoud, M.A., Tarhini, A., and Nasr, J.A. (2009) 'Decentralised approaches to wastewater treatment and management: applicability to developing countries’, Journal of Environmental Management 90: 652-9. doi:10.1016/j.jenvman.2008.07.001

Muspratt, A., Nakato, T., Niwagaba, C., Dione, H., Kang, J., Stupin, L., Regulinski, J., Mbeguere, M., and Strande, L. (2014) 'Fuel potential for faecal sludge: calorific value results from Uganda, Ghana and Senegal', Journal of Water Sanitation and Hygiene for Development 4(2): 223. DOI: 10.2166/washdev.2013.055

Taylor, M., Clarke, W.P., and Greenfield, P.E. (2003) 'The treatment of domestic wastewater using small-scale vermicompost filter beds’, Ecological Engineering 21(2-3): 197-203. doi:10.1016/j.ecoleng.2003.12.003

Thye, Y.P., Templeton, M.R., and Ali, M. (2011) ‘A critical review of technologies for pit latrine emptying in developing countries', Critical Reviews in Environmental Science and Technology 41(20): 1793-819 <http://dx.doi.org/10.1080/10643389.2010.481593>.

Wang, L., Guo, F., Zheng, Z., Luo, X., and Zhang, J. (2011) ‘Enhancement of rural domestic sewage treatment performance, and assessment of microbial community diversity and structure using tower vermifiltration', Bioresource Technology 102: 9462-70. doi:10.1016/j.biortech.2011.07.085

Xing, M.Y., Li, X.W., and Yang, J.A. (2010) 'Treatment performance of small-scale vermifilter for domestic wastewater and its relationship to earthworm growth, reproduction and enzymatic activity', African Journal of Biotechnology 9(44): 7513-20. 
C. FURLONG et al.

Xing, M.Y., Yang, J.A., Wang, Y.Y., Liu, J., and Yu, F. (2011) ‘A comparative study of synchronous treatment of sewage and sludge by two vermifiltrations using an epigeic earthworm Eisenia fetida', Journal of Hazardous Materials 185(23): 881-8. doi:10.1016/j.jhazmat.2010.09.103

Xing, M., Zhao, C., Yang, J., and Lv, B. (2014) 'Feeding behaviour and trophic levels of earthworms and other predators in vermifiltration system for liquid-state sludge stabilisation using fatty acid profiles’, Bioresource Technology 169: 149-54 <http://dx.doi.org/10.1016/j.biortech.2014.06.083>.

Zhao, L.M., Wang, Y.Y., Yang, J., Xing, M.Y., Li, X.W., Yi, D.H., and Deng, D.H. (2010) 'Earthworm microorganism interactions: a strategy to stabilize domestic wastewater sludge’, Water Research 44: 2572-82. doi:10.1016/j.watres.2010.01.011

Zhao, C., Xing, M., Yang, J., Lu, Y., and Lv, B. (2014) ‘Microbial community structure and metabolic property of biofilms in vermifiltration for liquid-state sludge stabilisation using PLFA profiles’, Bioresource Technology 151: 3406. doi:10.1016/j.biortech.2013.10.075 